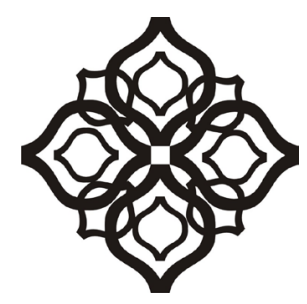

Shirkah

Journal of Economics and Business 


\section{Shirkah}

Journal of Economics and Business

Vol. 2, No. 2, May-August 2017

ISSN: 2503-4235 (p); 2503-4243 (e)

\section{Editor in Chief}

Sri Walyoto

\section{Editorial Boards}

Abu Umar Faruq Ahmad, UBD School of Business and Economics, Brunei Darussalam

Amelia Fauzia,

Asia Research Institute, National University of Singapore, Singapore

Cedomir Nestorovic,

ESSEC Business School Asia Pacific, Singapore

Dwi Condro Triono,

Faculty of Islamic Economics and Business, IAIN Surakarta, Indonesia

Fahmy Radhi,

Faculty of Economics and Business Universitas Gadjah Mada, Yogyakarta,

Indonesia

Hasan Basri,

Syiah Kuala University, Aceh, Indonesia

Johan Fischer,

Department of Social Sciences and Business Roskilde University, Denmark

Masudul Alam Choudhury,

Postgraduate Program in Islamic Economics and Finance, Trisakti University,

Jakarta, Indonesia and the College of Economics and Political Science (CEPS) in

Sultan Qaboos University (SQU), Oman

M. Falik Isbah,

School of Humanities and Social Science, University of New South Wales, Australia M. Ishaq Bhatti,

La Trobe Business School Department of Economics and Finance La Trobe

University, Australia

Najib Kailani,

Pascasarjana, Universitas Islam Negeri (UIN) Sunan Kalijaga, Yogyakarta, Indonesia 
Nunung Nurul Hidayah,

Aston Business School, Aston University, Birmingham, United Kingdom

Shaikh M Ghazanfar,

Departement of Economics, University of Idaho, Russian Federation

\section{Managing Editors}

Fitri Wulandari

Jasanta Perangin-angin

\section{Assistant to Editor}

M. Endy Saputro

M. Zainal Anwar

Supriyanto

Shirkah Journal of Economics and Business is a peer-reviewed journal published three times a year (January-April, May-August and September-December) by Faculty of Islamic Economics and Business, Institut Agama Islam Negeri (IAIN/ State Institute for Islamic Studies) Surakarta Central Java, Indonesia. The main objective of Shirkah is to offer an academic space of exchange ideas and initiate the increase number of qualified article produced by postgraduate students, practitioners and academicians.

\section{Editorial Office}

Ruang Jurnal Shirkah

Ground Floor, West Gate,

Faculty of Islamic Economics and Business

IAIN Surakarta

Jln. Pandawa No. 1, Kartasura, Sukoharjo, Jawa Tengah Kode Pos. 57168

Phone (+62271) 781516 Fax: (+62271)782336

E-mail: shirkahiainsurakarta@gmail.com

Website: http://shirkah.or.id/ 


\section{Shirkah}

Journal of Economics and Business

Vol. 2, No. 2, May-August 2017

ISSN: 2503-4235 (p); 2503-4243 (e)

\section{Table of Contents}

\section{Articles}

Shairil Izwan Taasim

Ramali Yusoff

An Instrument Developing Cashless in Malaysia

Aam S. Rusydiana

Irman Firmansyah

Efficiency versus Maqasid Sharia Index An Application on Indonesia

Islamic Bank

Azhar Ibrahim

The Call for Islamic Economics Shades of Contestation

Warsono

Deferred Tax Assets and Deferred Tax Expense Against Tax Planning Profit Management

Lisdawati Arifin

Earning on Response Coefficient in Automobile and Go Public

Companies

Farihatul Qamariyah

Waroeng Steak: Spritual Company in the Context of Post-Capitalism 


\title{
Waroeng Steak Spritual Company in the Context of Post-Capitalism
}

\author{
Farihatul Qamariyah \\ Center for Religious and Cross-Cultural Studies, Graduate School \\ Universitas Gadjah Mada \\ farihatulqamariyah@gmail.com
}

\begin{abstract}
'Management' at the business capitalism covers the vehicle of some aspects including the employee, course, service, network, and any kind of stuffs related to this case. In line with the system of business management, every single company might be in uniformity according to the common standard of capitalism despite having differences in the vision and mission. In this case, Waroeng Steak (WS) Restaurant in Demangan, Yogyakarta intentionally applied Islamic spiritual management. WS uses several kinds of teachings and trainings according to Islamic Sharia in the daily process. This concept concerns to the employees' behavior upgrading and company progression through WS' timeline program including daily, weekly, and annually activity striving for a great spiritual and economic orientation in the future. This paper argue despite the spiritual training for employees of WS might not be considered practical by capitalist standard, it is effective in bringing both spiritual and economic benefits to both company and all members of the staff. The research result that capitalism meet religion in terms of the production could lead to another standpoint at the collaborative intention in gaining positive benefit in successful business operation. Religion in regard to spiritual management in business has a significant role in bringing both individual upgrading in the class of devotion to God and the reflection to the good ethic in undergoing the working process, it is finally so-called a spiritual company that will be distinctively differ from the other existential companies.
\end{abstract}

Keyword: spiritual management, employees' habit, company characteristic upgrading 


\section{Introduction}

In $20^{\text {th }}$ century, a stage of capitalism has been widely recognized as one of the significant points in the process of globalization. In particular, this case is importantly viewed when it comes to the economic aspect within a business sphere in terms of company. In the system of undergoing a business in the capitalism context, so-called "management" becomes the thick portion of company in regard to the process of it. This management covers the vehicle of some aspects including the employee, course, service, network, and any kind of stuffs related to this case. In line with the system of business management, every single company might be in uniformity according to the common standard of capitalism despite having differences in the vision and mission.

Conversely, the issue of business management of certain company seems to be excited to be figured out when it attaches to a religious contact, in the concept of spirituality. Spiritual company is an idea which is in concern going to be discussed later in this paper. Spirituality here is implemented through the management used in a company (Abdullrahim, 2017). Regarding to this case, it can be perceived that the globalization appearance could lead every aspect of life in an instance of economical production to the spectacle of integrating and interconnecting one sector to another one in the sense of gaining more benefits and advantages. It is in need of successful orientation particularly in this topic that concerns with the case when business sector meets religious land (Sharma, 2017; Nisha, 2017). In other words, business is no longer engaging with merely capitalist matter and its process of production, yet it could be in contact with a religion, a devotion to the deity, and its spiritual management.

In this paper, I take the case of Waroeng Steak Restaurant in Demangan, Yogyakarta. Its location is the first place established in 2000 before having several branches in the level of regional and national position in Indonesia.It is a culinary restaurant in which the main menu 
is steak commonly known from European food, but it wraps up in several categories. Deliberately, I will not concern with the food issue deeply here, but the spiritual management that is actualized by the company in the execution of business process is the main issue in regard to this paper work.

The significant reason in choosing WS (abbreviation: Waroeng Steak) is because this company could be considered as having different management in use for operating the business compared with the other common companies. It refers to the management training of the employees as the member of the company who could potentially bring the good image for the future development. Islamic spiritual management is actualized by this company; therefore I argue that this case can be labeled as a spiritual company. WS uses several kinds of teachings and trainings according to Islamic Sharia in the daily process. The concept concerns the employees' behavior upgrading and company progression through WS' timeline program including daily, weekly, and annually activity striving for a great spiritual and economic orientation in the future.

Taking the case which concerns with a spiritual management in taking Islamic framework of dealing with the process, I connect it with the concept of spiritual economy proposed by Daromir Rudnycky (2009). This concept indeed supports this observation where a capitalist form fits to the Islamic ethics in working the business agenda. Rudnycky examines his research by observing a company of PT. Krakatau Steel and ESQ Leadership Centre and witnessing how these factories work on religious resurgence in dealing with neoliberalism and economical existence.

Furthermore, it is significant in having these conversations regarding the issue of capitalism which implemented in business of company and the product, engaging a religious spectacle especially Islamic aspect, and putting the spot of globalization in terms of spiritual economies. Those interactions create another worldview and image in this globalized world. 
In particular, when there is no border among the sectors in human life, it can globalize the spot of interaction between one to another that can give birth toward a wider contextual engagement. In addition, analyzing spirituality when it connects to capitalism, it exhibits another standpoint of the emergence of incorporation in the sense of economical orientation. Also, this significance refers to the spectacle of religion in the development of capitalism which nowadays might be practical in a way.

Through the observation and such interview sections as with the manager and the employee of WS in particular time, I finally draw three important questions regarding this discussion. They are revealing out the spiritual trainings and teachings that are provided by the management of Waroeng Steak to the employees and some social events, understanding the influence of those things toward the individual development both a personally updrading and a work performance during the activity and its process, and how they, the member of the company, evaluate their position in regard to capitalism as a part of globalization process. Consequently, my arguments in line with this case is despite the spiritual training for employees of WS might not be considered practical by capitalist standard, it is effective in bringing both spiritual and economic benefits to both company and all members of the staff. The interplay among business and religious spectacle in the context of globalization, in the evaluation, could lead a company and its members to the better development.

\section{Spiritual Managements and Trainings}

It was $2^{\text {st }}$ December 2014, I began my interview session with WS' manager as well as employee named Ali Hartawan. I did it at evening and by accidental moment, I had to wait for him a few minutes because he was doing an obligatory evening prayer together, jama'ah (in Arabic term), with a few of other members of the restaurant. I got an interesting topic in 
this landscape. It is in knowing the traditional religious practice in having prayer together, since not all companies have this kind of ritual. They, the member of the restaurants, are even provided a particular rest time for doing prayer together even though they actually can do it individually. Indeed, this activity is one of the religious traditions included in WS' spiritual management.

In the early qualification of having such of selection for WS' employees, it has some particular characteristics that must be fulfilled by people who are going to register to the member of the restaurants. WS only recruits men as the employees. The significant thing is they have to be Muslim with some religious qualifications such as ability of reciting alQuran and Islamic prayers besides having a good characteristic in work and public service as the common qualifications in business recruitment. Even though they do not fluent enough in these skills, they will be facilitated to be guided and trained later by WS' management.In according to my analysis, I classify the spiritual management executed by WS in three characteristics: individual exercise, company objective, and public service. These three classifications rely on sharia Islam including Islamic values and norms. The origin of sharia sources refers to the Quran as the work and will of God, the Sunna as the customs and practices of Muhammad Prophet's words and deeds, Islamic law and individual conscience (Rizk, 2008). In brief, this management is to provide a leadership treatment for the personal and work dedication based on Islamic principles.

Indicating the orientation in the context of capitalism, it elucidates a major point in each of the classification above. The first classification which is individual exercise, in line with Hartawan's explanation, this management focuses on personal enhancement of the employees on religious practices as the habitual activities. It coves prayer including obligatory and recommendatory prayer, recitation, and charity with 
individual awareness. In the actualization, the obligatory prayer is the five prayers as the general Islamic tradition and the recommendatory prayer is such a morning prayer called dhuha, and dawn prayer called tahajjud in which these rituals have some significance in the substantial practice. The recitation, the members of the company have a religious daily agenda called One Day One Juz, in which, they are suggested to read 10 pages as the part of Al Quran's verses. Last, the charity means personal willingness to share what they have even a little to the appropriate target. These kind of exercises are daily actualized by the employees as the manifestation of devotion to God through the period of working process.

The following element of the classification in regard to the spiritual management of WS is a company objective. It refers to WS' objectives for integrating Islamic teaching with working duty. The previous classification is still contributed to this second aspect. One of the implementation is praying together in sidelines during the working process, when the exact time for praying comes, the employees will split themselves up between one and another in having prayer, three and four members for instance. This tradition deliberately has a meaningful significance in which giving an instruction to be discipline with the collective intention. In brief, there is no reason to leave out this ritual even in the busy condition. This tradition might be practical in a way of working process as well that implemented in appreciating time and working deadline. In addition, the company provides an Islamic boarding school for the employees in reaching an effective process in the activity in supporting the individual exercise. Afterwards, there is an annual program for that is ESQ (Emotional and Spiritual Quotient) for the employees' spiritual input for selfacknowledgment and innate characteristic as the basic guidance for work and home intention. Then, the management also provides biweekly sermon for the employees by inviting a religious teacher as the media to increase 
and enrich their spiritual and religious knowledge as the foundation of undergoing the religious practices. Another, it is a monthly program that recites a completed verses of $\mathrm{Al}$ Quran within a particular time. And the annual program is a big charity such as giving 1000 plates of steak for 1000 orphanages spread out in over Indonesia regency through WS' branch of restaurants. This program depicts a deep objective which is the sense of gratefulness on the company development as well as marketing orientation in public sphere. These slight spiritual management actualized in several religious agenda possess an important meaning for political interest toward religious expectation, social orientation, and economical purpose (Palupi, 2017; Newaz, 2016).

Furthermore, the third classification is a public service. In details, WS not only provides spiritual program for the employees as the member of the company but it also creates some events addressing to the society nearby it, people who lives surrounding. This program is biweekly which accommodates around 200 people. The purpose is also in the sense of serving a lot of people in terms of spiritual need packaged in the sermon and recitation. Another service is social events in the particular moment, in Islamic celebration for example. A charity program is kind of important agenda that is created in several organizations as it has been explained in the previous description. Therefore, WS' movement in spiritual action does not merely address to the employees and the company, but also for many people who are in contact with it either in terms of location and cooperation.

Finally, those kind of spiritual managements are carried out since 2007 until now after 6 years of WS' establishment. Definitely, every single program that is managed under the umbrella of Islamic teaching within norm and value has a significant position attaching the company's future orientation and expectation. If I make a comparative analysis with 
Weber's issue on religion and capitalism, there is a tight relation in this case. The concept of spirit of capitalism can be considered as the pioneer depiction in scientific discourse on how religion plays an important role in the human economic development (Peifer, 2017; Scherer, 2017). The more prosper people, the more people indicated as the blessed one in the context of religious, social, and economic environment (Pals, 2008). Even though Weber in his contextual observation take as case of Protestant in regard to Calvinist and Lutheran denomination, this essential substance in this aspect has a similarity in the orientation. In consequences, WS's program toward the employees and its management underline at prosperity development for the future condition.

\section{Employees' Habit and Company Characteristic Upgrading}

The spiritual management was executed by WS in 2007. Hartawan told in such a comparison of WS's condition before that particular period and after the execution of the spiritual management. Every single spiritual program has convinced them in such good development and revolutionary situation. There is a big transformation effected to WS' development either spiritual or economic benefits for the company in general and all members in particular. In the individual upgrading referring to the employees' benefit, Hartawan confessed that he could get two aspects of benefits which are in uniform; they are material and spiritual enhancement. In the material aspect, there is a sufficient wealth and considered as blessed in it for his life fulfillment. In the spiritual aspect, he could devout to God in the ordinance and discipline condition. He convinces that by working process in WS is not only about fulfilling financial need but also about spiritual income. He conceptualizes the process of working in dedication of company impliedly as the manifestation of dedicating oneself to God. Working is a worship in brief saying. There is so much blessing he counts 
on the spiritual management he actualizes in the everyday life without considering them as a burden. And the final satisfaction in the result of this aspect is the destination of happiness and blissful life.

In the important transformation is the work ethic. By undergoing the spiritual managements, the employees' behavior in working process increasingly qualified. Consciousness in business is the significant one. From the individual upgrading of the employees take effects to the enhancement of the working enthusiasm. Hartawan could evaluate this condition including the different atmosphere of the employees' transformation because he had been working in WS since 2001. In the pragmatic result, WS' turnover in regard to business profit increases around $70 \%$ in advance. It can be seen that the transformation is the result of individual exercise which lead to a good work ethic and finally it effects to the company development.

A company upgrading can also be observed from the context of popularity. Every single good transformation in the context of capitalism plays a consequent position. WS' transformation after having the spiritual management for some classification has a good impact for its popularity. Nowadays, it becomes one of the famous and most visited restaurants in Yogyakarta and finally having for about 50 outlets in over Indonesian regency (waroengsteakandshake.com). From the context of popularity, WS globalizes its location with still in the persistent management in the framework of Islamic business ethics which fits to the Al Quran and Islamic tradition.

\section{Contextualizing Globalization in Business Production}

This part is the significant point in understanding the context of globalization in the spectacle of capitalism and its connection to religious landscape. The problem of economic crisis is the reason why nowadays 
spiritual management is needed. In accordance with Rudnycky's text (2009: 119) in evaluating ESQ's substantial program based on Ari Ginanjar's view, ESQ's CEO, the economic crisis in Indonesia that nowadays comes to the global problem such as corruption, deception, shiftlessness, and etc, is the indication of spiritual problem, therefore regarding to the solution, first thing that must be concerned in the effective way out is by actualizing the spiritual instruction in management through the principle of business success and personal development according to the Islamic literature. WS' movement is one of the appropriate examples in dealing with this case. In my evaluation, WS' management is in the participation of solution in regard to the crisis of economy in regard to spiritual problem. When religion has been positioned in the place of capitalist environment, the exploration of meaning could be discovered in which religion is not merely for the religious orientation but it also benefits to the other interdisciplinary aspect of social and economy (Snarr, 2017; Mike, 2017). Spiritual management in this case could be the medium of the intervention of spiritual problem (Rudnycky, 2009: 120).

In the other analysis, contextualizing WS'product of culinary business, steak which is basically European food but it utilizes the local ingredients, this issue fits to the concept of glocalization as one of the tools of understanding the existence of globalization which is stated in Vasquez and Marquardt' text (Robertson 1995; Wilson and Dissanayake 1996). This concept is a process of interacting and adapting the global issue within a particular practice, instrument, or even product to the local prosperities. WS' idea is in the participation of entering the global practice, European in Western product, in the context of utilizing what local have, in the case of Indonesia. The inclusive process of global and local aspect in the dynamic interaction (Voll, 2008: 256).

In the subsequent evaluation regarding to the interview session, the evaluation of WS' employees' position in regard to capitalism as a part 
of globalization process is convincing positively indeed. It can be viewed from the narrative how they, all members and staffs' WS, recognize the globalization by following the trends in it for striving a success. They admit that the standard of capitalism in general should be participated actively within the system and management. Yet, another positive standpoint here, they see themselves in differently view from the other company's program in managing the system. The difference is the significant vision of WS' company. It could lead them in defining what success is. The success which covers a religious and economic spectacle walking together at all once elucidates an important God's spot in the public sphere. For them, the development of some divisions including the religious and social aspect is the starting point in dealing with the company outline target for the success. Those are implemented in some social activities that is in the coexistence with the spiritual intention as the manifestation of religious devotion.

Another point how the members of WS understand their position in today's globalized world in terms of capitalism, in evaluation, the use of media as the suitable tool in declaring their identity as the spiritual company through some spiritual and social programs and events. The identity here, one of them, could be interpreted in terms of religious identity and company branding. As it has been narrated above about the qualification of becoming WS' employee is one should in the affiliation of Islam. In the analysis, religious identity is the local aspect while the capitalism status is the global one. To support this argument, I take Cunningham's idea (1999: 584) on the construction of self-identity utilized a rhetorical and symbolic resources in defining one's position in the context of global view in exploring a political economy in capitalism aspect. Definitely, there is a power relation in dealing with this case, the qualification of the identity, in doing the process of business. In addition, the application of spiritual 
management is as well the instance of identity construction in regard to the company demonstration (Yeniaras, 2017).

Forth, it still relates to a power relation. Evaluating the spiritual management in the context of globalization fits to the framework of neoliberalism theory. The practice of capitalism in economic orientation maximizes the advance of human being transforming to human working in the public interest which might be under control of the state and such institution (Harvey, 2007: 22). The authoritative management in WS deals with an advance system to train the employees for the maximal objectives. Again, these kind of treatments and managements under the purpose of progressive development either spiritual or economic expectation which finally result in a just future condition.Also, the spiritual management can be considered as the media for affiliating the company in the globalized conversation of capitalism because by having educated and religious employees with a good qualification of skill would be in advance in the competitive market and progressive network.

\section{Conclusion}

To some extent, the actualization of spiritual management based on Islamic Sharia by Waroeng Steak restaurant toward its employees and the company's activity in the context of capitalism and business arrangement creates a substantial significant meaning in the progressive development. The development emphasizes at the spiritual and economic enhancement through some daily and periodic religious, spiritual, and social programs by inviting all participants related to the members and the people in contact with WS under the network of cooperation and demographic position. Those participants get the positive benefits either individually upgrading, company objectives, and the social relation. Yet, the important one is about a spiritual dedication to the deity, in which, the implementation of 
working agenda is the manifestation of worship not merely an economic orientation.WS restaurant finally could consistently execute this model of management due to the successful target and purpose in the competitive globalized situation of market is in line with the outlining expectation. Indeed, religious spectacle within spiritual economy of management here means a lot in defining the company's identity and development.

In addition, the learning point that can be reached out in this case is about the integration of religious landscape and economic sphere. When capitalism met religion in terms of the production, it could lead to another standpoint at the collaborative intention in gaining positive benefit in successful business operation. In conclusion, religion in regard to spiritual management in business has a significant role in bringing both individual upgrading in the class of devotion to God and the reflection to the good ethic in undergoing the working process, it is finally so-called a spiritual company that will be distinctively different from the other existential companies.

\section{References}

Abdullrahim, N., Robson, J. The Improtance of Service Quality in British Muslim's Choice of an Islamic or Non-Islamic Bank Account. Journal of Financial Services Marketing 22 (2), pp. 54-63.

Cunningham, H. (1999). "The Ethnography of Transnational Social Activism: Understanding the Global as the Local Practice." American Ethnologist 26:3

Hartawan, A. (2014). Interview with the manager of Waroeng Steak Restaurant. December 2\&16. 
Harvey, D. (2007). "Neoliberalism as Creative Destruction." AnnalsAAPSS 610

Mike, K. (2017). The Intellectual Orders of a Market Economy. Journal of Institutional Economics, pp. 1-17.

Newaz, F.T., Fam, K.-S., Sharma, R.R. (2016). Muslim Religiousity and Purchase Intention of Different Categories of Islamic Financial Products. Journal of Financial Services Marketing 21 (2), pp. 141-152.

Nisha N., Iqbal, M. (2017). Halal Ecosystem: Prospect for Growth in Bangladesh. International Journal of Business and Society 18 (S1), pp. 205-222.

Pals, D. L. (2008). Introducing Religion. New York: Oxford University Press.

Palupi, M., Romadhon, R.W., Arifan, N. (2017). The Importance of Optimization of Halal Tourism: A Study of the Development of Halal Tousrism in Indonesia. Proceedings of the 29th International Business Information Management Association Conference -Education Excellence and Innovation Management Through Vision 2020: From Regional Development Susainability to Global Economic Growth, pp. 3083-3092.

Peifer, J.L., Johnson, D.R., Ecklund, E.H. (2017). The Moral Limits of the Market: Science Commercialization and Religious Traditions. Journal of Business Ethics, pp. 1-15.

Rizk, R.R. (2008) "Back to Basics: An Islamic Perspective on Business and Work Ethics.” Social and Responsibility Journal 4(1/2)

Rudnycky, D. (2009). “Spiritual Economies: Islam and Neoliberalism in Contemporary Indonesia.” Cultural Anthropology 24:1

Scherer, B., Waistell, J. (2017). Incorporating Mindfulness: Questioning Capitalism. Journal of Management Spirituality and Religion, pp. 1-18.

Sharma, R.-R., Newaz, F.T., Fam, K.-S. (2017). Muslim Religiousity, Generational Cohort and Buying Behaviour of Islamic Financial Producs. Australian Journal o Management 42 (3), pp. 482-501. 
Snarr, C.M. (2017). Elaborating Faith: Labor and Interfaith Resistance to Economic Ineuality. Journal of Religious Ethics 45 (2), pp. 255-277.

Vasquez, (2003).M. A. and Marie F. M."Theorizing Globalization and Religion." Globalizing the sacred: religion across the Americas. Rutgers

Voll, J. O. (2008) “Tran-state Muslim Movements and Militant Extremists in an Era of Soft Power." Banchoff, Thomas F, ed. Religious Pluralism, Globalization, and World Politics, Part 2: 10 New York: Oxford University Press

Website, http://waroengsteakandshake.com, Accessed in December 16, 2014.

Weber, M. (1992).The Protestant Ethics and the Spirit of Capitalism. London: Routledge.

Yeniaras, V. (2017). Unpacking the Relationship between Materialism, Status Consumption and Attitude to Debt: The Role of Islamic Religiousity. Journal of Islamic Marketing, 7 (2), pp. 232-247. 


\section{Shirkah Author Guidelines}

Shirkah currently offers two routes to submit manuscripts. We highly recommend to submit the articles which are made using OJS (Open Journal System). Feel free register as author soon through visiting http:// shirkah.or.id/index.php/home/user/register. The authors may directly send their manuscripts, along with their resume, to shirkahiainsurakarta@ gmail.com. Please prepare your manuscripts, using following guidelines:

1. Manuscript must be written in English. Submitted articles should not have been published or be under review for publication with another journal.

2. Manuscript's length is about $15-20$ pages, typed in one-half spaced on A4-paper size.

3. Manuscript must include an $150-200$ word abstract and keywords.

4. Manuscript must be arranged as follows: Title, Name of Author, E-mail address, Abstract, Keywords, Introduction (including method if any), Discussion, Conclusion, References.

5. Manuscript's titles not more than ten words.

6. Manuscript must be submitted in Microsoft Word or RTF.

7. Arabic words should be transliterated according to the style of International Journal of Middle Eastern Studies.

8. Manuscript references are preferably derived from the up-to-date references.

9. The author's resume should be submitted separately, consisting of at least full name, institutional address, phone number, areas of studies, and recent publications (if any).

10. Shirkab use APA Style 6th edition (2010) as reference format writing. We suggest the use of a reference manager software such as Mendeley, Zotero, and Endnote at templating the citation style. APA Style to be used is as follows: 


\section{Book with single author}

Swann, G. M. Peter. (2014). The Economics of Innovation an Introduction. Cheltenhum \& Northampton: Edward Elgar.

in-text citation: (Swann, 2014)

\section{Articles in reference books}

Alatas, S. F. (2006). Islam and the Science of Economics in Abu Rabi', I.M. The Blackwell Companion to Contemporary Islamic Thought. USA: Willey-Blackwell (pp. 587-606).

in text citation: (Alatas, 2006)

\section{E-Book}

Hackett, Rosalind (2007). "Religous Dimentions of War and Peace: Introduction.” Dalam Gerrie ter Haar dan Yoshio Tsuruoka (Ed.), Religion and Society: An Agenda for the 21st Century (h. 3-6). Retrieved from http:// brill.nl.

in text citation: (Hackett, 2006)

\section{Master's thesis, from a commercial database}

McNieI, D. S. (2006). Meaning through narrative: A personal narrative discussing growing up with an alcoholic mother (Master's thesis). Available from ProQuest Dissertations and Theses database. (UMI No. 1434728)

in text citation: (Mc Niel, 2006)

\section{Doctoral dissertation, from an institutional database}

Adams, R. J. (1973). Building a foundation for evaluation of instruction in higher education and continuing education (Doctoral dissertation). Retrieved from http://www.ohiolink.edu/etd/

in text citation: (Adams, 1973) 


\section{Doctoral dissertation, from the web}

Bruckman, A. (1997). MOOSE Crossing: Construction, community, and learning in a networked virtual world for kids (Doctoral dissertation, Massachusetts Institute of Technology). Retrieved from http:/www-static. cc.gatech.edu/--asb/thesis/

in text citation: (Bruckman, 1997)

\section{Journal article with No DOI}

Bourkhis, K., and Nabi, M. S. (2013). Islamic and conventional banks' soundness during the 2007-2008 financial crisis. Journal Metrics, 22(2), 68-77.

in-text citation: (Bourkhis \& Nabi, 2013).

\section{Journal article with DOI}

Ichwan, M. (2012). The Local Politics Of Orthodoxy: The Majelis Ulama Indonesia in the Post-New Order Banten. Journal Of Indonesian Islam, 6(1), 166-194. doi:http://dx.doi.org/10.15642/JIIS.2012.6.1.166-194

In text citation : (Ichwan, 2012)

\section{Abstract as citation}

Hasan, N. (2012). Islamist Party, Electoral Politics And Da'wah Mobilization Among Youth : The Prosperous Justice Party (PKS) in Indonesia. Journal of Indonesian Islam, 6(1), 17-47. Abstract from http:// jiis.uinsby.ac.id/index.php/jiis/article/view/97

in text citation : (Hasan, 2012)

\section{Mass media article}

Sahal, Akhmad (2014, March 2). Kiai Sahal dan Realisme Fikih.Tempo Magazine, p. 120.

in text citation : (Sahal, 2014) 


\section{Research report}

Fisher, B. S., Cullen, F. T., \& Turner, M. G. (2000). The Sexual Victimization of College Women. Research Report.

in text citation : (Fisher, Cullen, Turner, 2000)

\section{Monograph}

Routray, Bibhu Prasad (2013), National Security Decision-Making in India (RSIS Monograph No. 27). Singapura: Rajaratnam School of International Studies.

in text citation : (Routray, 2013)

\section{Proceeding article}

Sudibyakto, Hizbaron, D.R., \& Jati, R (Ed.) (2009), Proceeding International Seminar Disaster Theory, Research and Policy. International seminar held by Sekolah Pascasarjana, Universitas Gajahmada, Yogyakarta, 8-9 Desember 2009.

in text citation : (sudibyakto and Jati, 2009)

\section{Paper conference/seminar/symposium}

Janutama, Herman Sinung (2011). "Kraton dan Hubungan Antar Agama." Paper presented in Seminar Kraton dan Panatagama held by Center for the Study of Islam and Social Transformation (CISForm), Yogyakarta, 17 November.

in text citation :(Janutama, 2011)

\section{Online article in web}

Shiva, (2006, February). Bioethics: A Third World Issue. Native-web. Diperoleh dari http://www.nativeweb.org/ pages/legal/shiva.html

in text citation : (Shiva, 2006) 


\section{Online research report}

Kessy, S. S. A., \& Urio, F M. (2006). The contribution of microfinance institutions to poverty reduction in Tanzania (Research Report No. 06.3). Retrieved from Research on Poverty Alleviation website: http://www. repoa.or.tz /documents_storage/Publications/Reports/06.3_Kessy_and_ Urio.pcif

in text citation : (kessy and urion, 2006)

\section{Holy book}

Qur an, $2(25)$

In text citation : (Q. al-Baqarah 2:25).

\section{Encyclopaedia}

Graycar, Adam (1992). Social Welfare Policy. Dalam Mary Hawkesworth dan Maurice Kogan (Ed.), Encyclopedia of Government and Politics (Vol. 1). London: Routledge.

in text citation : (Graycar, 1992)

\section{Interview}

Sultan Hamengkubuwono X (interview, 2011, April 19)

in text citation: (Hamengkubuwono, 2011)

\section{Documentary film}

Steijlen, Fridus (2008). A Day in the Life of Indonesia [documentary film, 58 minutes]. Leiden: KITLV Press.

in text citation : (Steijlen, 2008) 
Vol. 2 No. 2, May - August 2017 